\title{
SACRED HERITAGE
}

In this volume, Roberta Gilchrist critically evaluates the concept of sacred heritage. Drawing on global perspectives from heritage studies, archaeology, museology, anthropology and architectural history, she examines the multiple values of medieval Christian heritage. Gilchrist investigates monastic archaeology through the lens of the material study of religion and reveals the sensory experience of religion through case studies including Glastonbury Abbey and Scottish monasticism. Her work offers new insights into medieval identity and regional distinctiveness, healing and magic, and memory practices in the sacred landscape. It also reflects on the significance of medieval sacred landscapes as contested heritage sites which hold diverse meanings to contemporary groups.

This title is also available as Open Access on Cambridge Core at doi.org/ I0.1017/9781108678087

Roberta Gilchrist is Professor of Archaeology at the University of Reading. A pioneer of gender and life course studies in archaeology, she was elected Fellow of the British Academy in 2008, voted Current Archaeology's 'Archaeologist of the Year' in 20I6, and became an Honorary Fellow of Jesus College, University of Cambridge in 20I8. She is the author of several books, including Medieval Life: Archaeology and the Life Course and Gender and Material Culture: The Archaeology of Religious Women. 


\section{SACRED HERITAGE}

MONASTIC ARCHAEOLOGY, IDENTITIES, BELIEFS

\section{ROBERTA GILCHRIST}

University of Reading 


\section{CAMBRIDGE UNIVERSITY PRESS}

University Printing House, Cambridge Св2 8вs, United Kingdom

One Liberty Plaza, 20th Floor, New York, NY Iooo6, USA

477 Williamstown Road, Port Melbourne, vic 3207, Australia

3I4-32I, 3rd Floor, Plot 3, Splendor Forum, Jasola District Centre,

New Delhi - i10025, India

79 Anson Road, \#06-04/o6, Singapore 079906

Cambridge University Press is part of the University of Cambridge.

It furthers the University's mission by disseminating knowledge in the pursuit of education, learning, and research at the highest international levels of excellence.

www.cambridge.org

Information on this title: www.cambridge.org/978II08496544

DOI: IO.IOI7/978II08678087

(C) Roberta Gilchrist, 2020

This work is in copyright. It is subject to statutory exceptions and to the provisions of relevant licensing agreements; with the exception of the Creative Commons version the link for which is provided below, no reproduction of any part of this work may take place without the written permission of Cambridge University Press.

An online version of this work is published at doi.org/IO.IOI7/978II08678087 under a Creative Commons Open Access license CC-BY-NC-ND 4.0 which permits re-use, distribution and reproduction in any medium for non-commercial purposes providing appropriate credit to the original work is given. You may not distribute derivative works without permission. To view a copy of this license, visit https://creativecommons.org/licenses/by-nc-nd/4.o

All versions of this work may contain content reproduced under license from third parties. Permission to reproduce this third-party content must be obtained from these third-parties directly.

When citing this work, please include a reference to the DOI Io.IoI7/9781108678087

First published 2020

A catalogue record for this publication is available from the British Library.

Library of Congress Cataloging-in-Publication Data

NAMES: Gilchrist, Roberta, author.

TITLE: Sacred heritage : monastic archaeology, identities, beliefs / Roberta Gilchrist. Description: Cambridge ; New York, NY : Cambridge University Press, 2020. | Includes bibliographical references and index.

IDENTIFIERS: LCCN 20I9038I70 (print) | LCCN 20I9038I7I (ebook) | ISBN 978IIO8496544

(hardback) | ISBN 978IIO87339I5 (paperback) | ISBN 978II08678087 (epub)

Subjects: LCSH: Christian antiquities-Scotland. | Archaeology, Medieval-Scotland. |

Monasticism and religious orders-History-Middle Ages, 600-I500. | Archaeology and

religion-Case studies. | Sacred space-Conservation and restoration-Case studies. |

Material culture-Religious aspects-Case studies.

CLASSIFICATION: LCC BRI33.G72 S264 2020 (print) | LCC BRI33.G72 (ebook) |

DDC $274 \cdot \mathrm{I} / \mathrm{O} 3-\mathrm{dc} 23$

LC record available at https://lccn.loc.gov/2019038170

LC ebook record available at https://lccn.loc.gov/2019038I7I

ISBN 978-I-IO8-49654-4 Hardback

Cambridge University Press has no responsibility for the persistence or accuracy of URLs for external or third-party internet websites referred to in this publication and does not guarantee that any content on such websites is, or will remain, accurate or appropriate. 